ЛИТВИНОВ Вячеслав Петрович - кандидат исторических наук, независимый исследователь (Россия, Липецкая обл., г. Елеu; litwinov.slav@yandex.ru)

\title{
ПЕРВАЯ ЖЕЛЕЗНАЯ ДОРОГА В СРЕДНЕЙ АЗИИ И ЕЕ ОХРАНА: ИСТОРИКО-ПРАВОВОЙ АСПЕКТ
}

Аннотация. В статье рассматривается строительство первой железнодорожной магистрали в Средней Азии и учреждение Жандармского полицейского управления Закаспийской военной железной дороги для охраны и обеспечения порядка на ней. Автор исследует основные сведения о его штате, функциях и задачах деятельности в 1865-1905 гг.

Ключевые слова: Средняя Азия, Русский Туркестан, Закаспийская область, Закаспийская (Среднеазиатская) железная дорога, жандармское полицейское управление, чрезвычайная охрана

И стория отечественной железнодорожной полиции в дореволюционный период пока еще не получила должной и полноценной научной рефлексии, а проблема деятельности жандармских полицейских управлений железных дорог России - наименее изученная часть истории российской полиции [Реент 2001: 176]. Особенно обделенными в этом отношении оказались национальные окраины Российской империи, в т.ч. и Средняя Азия (Туркестан).

В царской России активное железнодорожное строительство началось позднее, нежели в странах буржуазной Европы и Америки. Тем не менее железная дорога Санкт-Петербург - Царское село была построена за полтора года, и ее открытие состоялось 1 октября 1837 г. Император Николай I был инженером по образованию и прекрасно понимал всестороннее значение железных дорог. Ему даже пришлось оказать нажим на собственное правительство (особенно на министра финансов Е.Ф. Канкрина) при решении вопроса о строительстве магистрали Санкт-Петербург - Москва. Понятно, что проблема была решена положительно ${ }^{1}$. В итоге весьма протяженная (по европейским меркам) железная дорога, связавшая обе столицы (так тогда называли Санкт-Петербург и Москву) была построена, но только через четверть века, после прихода к власти Николая I. Коль скоро тема данной статьи посвящена железнодорожной полиции, то следует отметить, что такой полиции в те времена не существовало. Строительство железных дорог и ее эксплуатацию охраняли воинские и жандармские подразделения.

Учреждение собственно жандармских полицейских управлений железных дорог (далее - ЖПУ ЖД) произошло уже при императоре Александре II, когда в России, освободившейся от крепостничества, началось бурное развитие капитализма, сопровождавшееся форсированным строительством передовых транспортных магистралей. Но это происходило преимущественно в центральных регионах империи, тогда как на национальных окраинах пока еще всецело преобладал водный и гужевой транспорт. Вместе с тем и они вскоре попали в орбиту железнодорожного строительства в стране, в т.ч. и Туркестан.

Можно, конечно, указывать на то, что строительство первой железной дороги в этом регионе, начатое в 1880 г., было завершено только в сентябре 1888 г.

${ }^{1}$ Именной, данный Сенату - Об учреждении особого Комитета и Строительной комиссии для устройства С-Петербургско-Московской железной дороги. 1 февраля 1842 г. - ПСЗРИ-2. Т. 17. Отд. 1. СПб. 1843. № 15265. С. 74-75; Высочайше утвержденный временный штат канцелярии Комитета и Строительной комиссии С-Петербурго-Московской железной дороги. 8 февраля 1842 г. - Там же. № 15279. С. 81. 
Однако, во-первых, во многих районах «внутренней» (т.е. центральной) России в указанный период вообще еще не было железных дорог, а, во-вторых, были ли такие магистрали в соседних с Туркестаном странах, например в Китайском Туркестане (Синьцзяне), Афганистане, Персии? Вопрос можно считать риторическим. В то время как с конца 1880-х гг. коренное население царского Туркестана (а равно и переселившееся сюда русскоязычное население) пользовалось «шайтан-арбой» (так местные жители называли Закаспийскую военную железную дорогу), жители указанных выше стран еще долго пользовались простыми арбами, а в Афганистане фактически и сегодня нет развитой железнодорожной сети.

Планы строительства железных дорог по направлению к Туркестану и внутри него рассматривались еще в 1860-1870-х гг. Эти проекты были разными, и в суммарном выражении о них еще в 1874 г. писала популярная российская газета «Голос» 1 . Нет необходимости подробно излагать их содержание - это заняло бы много статейного пространства. Однако заметим, что строительство первой в истории Средней Азии железной дороги (Закаспийской) было поистине героической эпопеей. Ее сооружение было крайне необходимо для упрочения военно-стратегических позиций России на южных рубежах империи, на которые имела свои виды Великобритания. Сооружение первого участка железнодорожной магистрали от Михайловского залива до Кизыл-Арвата было начато в мае 1880 г., осуществлялось в интересах II Ахалтекинской экспедиции генерала М.Д. Скобелева, было завершено в сентябре 1881 г. и потребовало огромных затрат ${ }^{2}$. Она прокладывалась в основном в песчаных пустынях. Многие не верили в возможность построения Закаспийской военной железной дороги (далее - ЗВЖД) и полагали, что ее быстро занесет песками и, таким образом, вместе с рельсами будут зарыты в землю и средства, на нее потраченные. Даже знаменитый генерал М.Г. Черняев, присоединивший Среднюю Азию к России, первый русский администратор в Туркестане (в 1865-1866 гг.) и второй его генерал-губернатор (в 1882-1884 гг.) в апреле 1886 г. выступил в известной газете тех лет - суворинском «Новом времени» - со статьей «Академическая железная дорога», в которой предрекал ей ту судьбу, о которой мы писали выше ${ }^{3}$. Однако следом в газете «Свет» вышла статья некоего В. К-ва, в которой тот писал: «М.Г. Черняев доказывает, что в Средней Азии нельзя строить железных дорог, ибо их засыплет песком! И что для спасения пути нужно будет на сотни верст строить галереи!.. Это ли речь серьезного человека?» В. К-ов писал в заключение: «Закаспийская железная дорога, так как она ведется теперь великое и совершенно необходимое государственное сооружение. Ее нельзя вести ни иначе, ни лучше. Успех сооружения - следствие энергии строительства М.Н. Анненкова вызвал много завистников и много врагов» ${ }^{4}$.

Время показало, что легендарный покоритель Средней Азии Черняев оказался не прав, тогда как генерал Анненков был щедро награжден императором Александром III ${ }^{5}$. В последующем опыт строительства ЗВЖД эффективно использовался европейскими колониальными державами в песчаных регионах

1 Голос. 1874. № 287. 17 окт.

2 Строительство было продолжено только во второй половине 1884 г. Стальная линия прошла через Ашхабад до Чарджоу, а после возведения в мае 1888 г. деревянного моста через Амударью открылось движение до Самарканда, и магистраль получила свое название - Закаспийская военная железная дорога (ЗВЖД).

3 Новое время. 1886. 1 апр.

4 Российский государственный архив древних актов (РГАДА). Ф. 1385. Д. 1218. Л. 10-11.

5 РГАДА. Ф. 1385. Д. 1218. Л. 43; Басханов М.К. 2005. Русские военные востоковеды до 1917 года: библиографический словарь. М.: Восточная литература. С. 17. 
своих лимитрофов. Следует отметить, что во время сооружения этой железной дороги полицейские функции по отношению к строителям и обслуживающему персоналу исполняли воинские подразделения Закаспийской области, подчиненные командующему Кавказским военным округом, а также специально сформированные железнодорожные батальоны, которые постоянно дислоцировались у главных станций дороги. После образования в феврале 1885 г. соответствующего подразделения ${ }^{1}$ в охране строительства ЗВЖД принимали участие и милиционеры-туркмены. Их конные отряды были, понятно, более мобильными, передвигались быстро, вовремя достигали нужных объектов. Для повышения эффективности железнодорожной службы туркмен-милиционеров 7 сентября 1887 г. был принят специальный правовой акт ${ }^{2}$.

Как отмечалось выше, учреждение ЖПУ железных дорог произошло только при императоре Александре II, когда в России протяженность железных дорог стала быстро нарастать. В царских указах о правах и обязанностях начальников жандармских полицейских управлений железных дорог от $1865,1867^{3}$ и 1868 гг. указывалось, что ЖПУ ЖД подлежали «ведению начальства Отдельного Корпуса жандармов», чтобы «определение, увольнение, переводы, поощрения, награды и ответственность всех означенных управлений зависели непосредственно от жандармского начальства» ${ }^{4}$.

Указанные нормативно-правовые акты приведены для того, чтобы прояснить вопрос, кому и как подчинялось ЖПУ ЗВЖД, учрежденное 12 июня 1890 г. ${ }^{5}$ Но вызывает интерес время принятия данного нормативно-правового акта. Дело в том, что до этого ЖПУ ЖД нередко учреждались еще во время их строительства 6 . В нашем случае это произошло уже после того, как Закаспийская военная железная дорога заработала во всю свою мощь. Возможно, что учреждение ЖПУ ЗВЖД затягивалось в связи с предполагаемыми изменениями статуса Закаспийской области - или присоединение ее к Туркестанскому генерал-губернаторству (краю), с которым она составляла единое территориальное пространство, поскольку, в отличие от Кавказа, не была отделена от него Каспийским морем, или же образование из нее особого «неотдаленного» округа, подчиненного непосредственно Военному министерству. В конце концов победила вторая точка зрения, которая была закреплена утвержденным 6 февраля 1890 г. «Временным положением об управ-

${ }^{1}$ Высочайше утвержденное Положение о Туркменской милиции Закаспийской области. 15 февраля 1885 г. - ПСЗРИ-3. Т. 5. СПб. 1887. № 2747 С. 63-64.

2 Высочайше утвержденное Положение Военного совета - Об увеличении числа урядников в Туркменской конной милиции. 7 сентября 1887 г. - ПСЗРИ-3. Т. 7. Отд. 1. СПб. 1889. № 4692. С. 400.

3 Именной, объявленный в приказе Военного Министра - О правах и обязанностях Начальников Полицейских Управлений Железных дорог. 16 августа 1865 г. - ПСЗРИ-2. Т. 40. Отд. 1. СПб. 1867. № 42402. С. 903-904. Именной, объявленный в приказе Военного Министра 8 января 1867 г. - Об обязанностях и подчинении Жандармских Полицейских Управлений железных дорог. - ПСЗРИ-2. Т. 41. Отд. 2. СПб. 1868. № 44071. С. 532.

4 Именной, объявленный в приказе Военного министра - O правах начальников Жандармских полицейских управлений железных дорог. 29 сентября 1868 г. - ПСЗРИ-2. Т. 43. Отд. 2. СПб. 1873. № 46300. С. 300.

5 Высочайше утвержденное Мнение Государственного совета - О сформировании Жандармского Полицейского управления Закаспийской железной дороги. 12 июня 1890 г. - ПСЗРИ-3. Т. 10. Отд. 1. СПб. 1893. № 6947. С. 533-534.

6 Именной, объявленный в приказе по военному ведомству - Об учреждении жандармско-полицейского надзора на строящихся железных дорогах. 6 марта 1873 г. ПСЗРИ-2. Т. 48. Отд. 1. СПб. 1876. № 51970. С. 306-307. 
лении Закаспийской областью» ${ }^{1}$. Начальником области был назначен генерал-лейтенант А.Н. Куропаткин, который вместе со знаменитым генералом М.Д. Скобелевым принимал участие в присоединении Туркмении к России.

У Куропаткина были напряженные отношения с начальником ЗВЖД генералом М.Н. Анненковым, но они разрешились в пользу нового начальника Закаспийской области - человека сурового, жесткого, но справедливого, за что он (об этом свидетельствуют многие архивные документы) пользовался большим авторитетом у коренного населения Закаспийского региона - туркмен, каракалпаков, узбеков и казахов.

По царскому законодательству, жандармы в военном отношении (как воинское подразделение) подчинялись военному министру, а по делам профессиональной службы - Отдельному корпусу жандармов (далее - ОКЖ), шефом которого считался министр внутренних дел. Более того, закон от 12 июня 1890 г. предписывал «предоставить чинам означенного Управления [ЖПУ ЗВЖД] права и преимущества, присвоенные военнослужащим в прочих частях Закаспийской области и Туркестанского военного округа» ${ }^{2}$. А практическая реализация этих прав и преимуществ была тоже не в столице, а в руках начальника Закаспийской области и одновременно командующего войсками в ней. Поэтому случаев, когда руководители ЖПУ ЗВДЖ вступали бы в острые конфликты с последним, в архивных материалах не отмечалось.

В соответствии с законом от 12 июня 1890 г. утвержденный штат ЖПУ ЗВЖД состоял из 120 чел. Его начальником мог быть полковник или даже генералмайор. Он получал, как отмечалось в указе, «жалованье по чину из усиленного оклада», а также независимо от своего звания в год так называемых столовых - 560 руб. 40 коп., добавочных - 600 руб. и разъездных - 600 р. В указе также отмечалось, что начальник ЖПУ ЗВЖД должен был одновременно исполнять и обязанности начальника одного из отделений вверенного ему управления. Ему же полагался личный адъютант из «обер-офицеров» с «жалованьем по чину из усиленного оклада», а также независимо от звания столовых 138 руб. и добавочных - 400 руб. в год. На разъезды адъютанту ничего не выделялось.

В штате ЖПУ ЗВЖД учреждались 4 должности начальников отделений, которые должны были состоять в звании ротмистров или подполковников. Каждому из них тоже полагалось «жалованье по чину из усиленного оклада», а также в год по 300 руб. столовых, 400 руб. добавочных и 200 руб. разъездных. Кроме того, по штату полагалось 5 должностей вахмистров с годовым окладом каждому в 240 руб. Никаких иных выплат они не получали. Самую большую категорию сотрудников ЖПУ ЗВЖД (107 чел.) составляли унтер-офицеры с годовым содержанием в 189 руб. 90 коп. каждому. Они тоже не получали ничего более. Для канцелярии ЖПУ ЗВЖД указ учредил две должности писарей, один из которых относился к так называемому среднему окладу (60 руб. в год), а другой - к низшему окладу (36 руб. в год). Предусматривались и выплаты на канцелярские расходы: начальнику ЖПУ ЗВЖД - 200 руб. в год, начальникам отделений - по 75 руб., вахмистрам и унтер-офицерам - по 5 руб. 3

Линия Закаспийской военной железной дороги проходила через г. Чарджуй,

${ }^{1}$ Высочайше утвержденное Положение об управлении Закаспийской области. 6 февраля 1890 г. - ПСЗРЙ-3. Т. 10. Отд. 1. СПб. 1893. № 6576 С. 70-75.

2 Высочайше утвержденное Мнение Государственного совета - О сформировании Жандармского Полицейского управления Закаспийской железной дороги. 12 июня 1890 г. - ПСЗРИ-3. Т. 10. Отд. 1. СПб. 1893. № 6947. С. 533.

3 Штат Жандармского Полицейского управления Закаспийской военной железной дороги. - ПСЗРИ-3. Т. 10. Отд. 1. СПб. 1893. № 6947. С. 404-405. 
расположенный на территории Бухарского ханства, который стал первым местопребыванием штаб-квартиры ЖПУ ЗВЖД. Закон от 12 июня 1890 г. в п. 3 устанавливал, что с 1 января 1891 г. офицерским чинам ЖПУ ЗВЖД, пребывающим в Чарджуе, отпуск порционных денег будет производиться наравне с прочими офицерскими чинами расположенного в этом городе гарнизона 1 . Что касается прочих чинов Чарджуйского отделения ЖПУ ЗВЖД (вахмистров, унтер-офицеров и писарей), то им полагались «порционные» в размере 25 коп. в сутки, что было неплохой выплатой, если учесть, что писарь «низшего оклада» получал всего 3 руб. в месяц.

Но самое любопытное заключалось в том, что ЖПУ ЗВЖД (как, впрочем, и все иные управления такого рода) финансировалось из бюджета Военного министерства. Так, на его содержание в 1891-1893 гг. предполагалось ежегодно ассигновать по 25629 руб. 52 коп. Кроме того, на организационный 1890 г. из сметы Закаспийской военной железной дороги выделялась единовременно сумма в 4874 руб. для приобретения обмундирования и оружия для всех чинов ЖПУ ЗВЖД². В конце 1895 г. в штат ЖПУ ЗВЖД добавили должности 1 начальника отделения и 12 унтер-офицеров ${ }^{3}$. В конце 1896 г. офицеров ЖПУ ЗВЖД лишили права на походные «порционные» деньги. Вместе с тем прежние выплаты были признаны правильными, и вычетов с них не производилось ${ }^{4}$.

В мае 1897 г. Военный совет Военного министерства постановил на период строительства постоянного моста через р. Амударью временно добавить в штат 4 унтер-офицеров с тем, чтобы по завершении сооружения уволить их. Кроме того, одному из начальников отделений ЖПУ ЗВЖД добавили 500 руб. на разъезды ${ }^{5}$. В августе 1897 г. правительство учредило жандармский полицейский надзор на Мургабской ветке ЗВЖД новое отделение ЖПУ дороги. В штат последнего включили 1 начальника отделения, 1 вахмистра и 27 унтер-офицеров. На время строительства ветки начальнику ЖПУ ЗВЖД было назначено 300 руб. разъездных, а начальнику отделения $-500^{6}$. Поскольку последнее курировало деятельность путевых сторожей на Закаспийской железной дороге, то степень его ответственности возросла после того, как Государственный совет разрешил путевым сторожам этой магистрали употреблять огнестрельное оружие во время исполнения своих служебных обязанностей ${ }^{7}$. В 1904 г. решение было

1 Высочайше утвержденное Мнение Государственного совета - О сформировании Жандармского Полицейского управления Закаспийской железной дороги. 12 июня 1890 г. - ПСЗРИ-3. Т. 10. Отд. 1. СПб. 1893. № 6947. С. 533-534.

2 Там же. С. 534.

3 Высочайше утвержденное Положение Военного совета - Об увеличении штата Жандармского Полицейского управления Закаспийской военной железной дороги. 16 декабря 1895 г. - ПСЗРИ-3. Т. 15. СПб. 1899. № 12289. С. 726-727.

4 Высочайше утвержденное Положение Военного совета - О производстве походных порционов офицерским чинам Жандармского управления Закаспийской военной железной дороги. 19 декабря 1896 г. - ПСЗРИ-3. Т. 16. Отд. 1. СПб. 1899. № 13547. С. 780.

5 Высочайше утвержденное Положение Военного совета - О временном увеличении штата Жандармского полицейского управления Закаспийской железной дороги. 10 мая 1897 г. - ПСЗРИ-3. Т. 17. СПб. 1900. № 14078. С. 265.

6 Высочайше утвержденное Положение Военного совета - Об учреждении жандармского полицейского надзора на Мургабской ветви Закаспийской железной дороги. 15 августа 1897 г. - ПСЗРИ-3. Т. 17. СПб. 1900. № 14492. С. 559.

7 Высочайше утвержденное Мнение Государственного совета - Об употреблении сторожами Закаспийской железной дороги оружия при исполнении служебных обязанностей. 31 января 1900 г. - ПСЗРИ-3. Т. 20. Отд. 1. СПб. 1902. № 18092. С. 71-72. 
распространено на всю сеть Средне-Азиатской железной дороги ${ }^{1}$. На исходе 1901 г. в связи с сооружением Бухарской ветки в штат ЖПУ Среднеазиатской железной дороги добавили 2 унтер-офицеров ${ }^{2}$.

В конце 1905 г. на Средне-Азиатскую железную дорогу было распространено действие закона о правилах чрезвычайной охраны на магистралях Российской империи ${ }^{3}$. На дороге создавались особые комитеты в составе управляющих дорог, заведующих передвижением войск и начальников ЖПУ железных дорог. В местностях, объявленных на положении чрезвычайной охраны, они подчиняются местным генерал-губернаторам как «главноначальствующим»4. Таким образом, главным командиром жандармов в Средней Азии становился туркестанский генерал-губернатор.

В функции ЖПУ ЗВЖД входило не только обеспечение должного порядка в так называемой полосе отчуждения, но и задачи политического сыска, поскольку (через ОКЖ) оно было причислено к Департаменту полиции МВД. Но то как оно справлялось с функциями и задачами такого сыска, является предметом отдельного исследования.

В конце XIX в. в жизни Закаспийской области, Закаспийской военной железной дороги и ЖПУ ЗВЖД произошли серьезные изменения. В начале ноября 1898 г. ЗВЖД была переименована в Средне-Азиатскую5. Следом она была передана из ведения Военного министерства в подчинение (с 1 января 1899 г.) Министерству путей сообщения ${ }^{6}$. Вместе с тем работники ЖПУ дороги по-прежнему финансировались Военным министерством, хотя и подчинялись через штаб ОКЖ министру внутренних дел.

В заключение можно прийти к выводу, что, несмотря на все сложности строительства транспортных магистралей, первая в Туркестане железная дорога сыграла значительную роль в жизни коренного населения региона и переселенцев из внутренних районов России, особенно в экономической сфере. Как и на всех других железных дорогах России, на Закаспийской военной железной дороге был учрежден жандармско-полицейский надзор в виде специального управления. Финансирование ЖПУ ЗВЖД (позже - Средне-Азиатской ЖД) осуществлялось военным министерством, но подчинялось оно МВД (штабу ОКЖ). ЖПУ ЗВЖД выполняло функции охраны «полосы отчуждения» и объектов, на ней расположенных.

\footnotetext{
${ }^{1}$ Высочайшее повеление, объявленное Министром путей сообщения - О распространении на всю сеть Средне-Азиатской железной дороги правил об употреблении путевыми сторожами оружия. 29 февраля 1904 г. - ПСЗРИ-3. Т. 24. Отд. 1. СПб. 1907. № 24146. С. 222.

2 Высочайшее повеление, объявленное Военным Министром - Об увеличении штата Жандармско-Полицейского Управления Средне-Азиатской железной дороги. 19 декабря 1901 г. - ПСЗРИ-3. Т. 21. Отд. 1. СПб. 1903. № 20866. С. 1209.

3 Именной, Высочайший указ, данный Сенату - О правилах чрезвычайной охраны на железных дорогах. 14 декабря 1905 г. - ПСЗРИ-3. Т. 25. Отд. 1. СПб. 1908. № 27043. С. 887-889.

4 Там же.

5 Высочайше утвержденный всеподданнейший доклад Министра путей сообщения - O присвоении Самарканд-Андижанской железной дороге с ветвями на Ташкент и НовоМаргелан наименования Средне-Азиатской железной дороги. 5 ноября 1898 г. - ПСЗРИ-3. Т. 18. Отд. 1. СПб. 1901. № 16032а. Дополнения к 18 т. ПСЗРИ-3. С. 71.

6 Высочайшее повеление, объявленное Министром путей сообщения - О передаче Закаспийской железной дороги в ведение Министерства путей сообщения. 18 декабря 1898 г. - ПСЗРИ-3. Т. 18. Отд. 1. СПб. 1901. № 16256. С. 1090.
} 


\title{
Список литературы
}

Реент Ю.А. 2001. Общая и политическая полиция России (1900-1917гz.): монография. Рязань: Узорочье. 284 с.

\section{FIRST RAILWAY IN CENTRAL ASIA AND ITS PROTECTION: LEGAL HISTORICAL ASPECT}

\begin{abstract}
The article examines the construction of the first railway in Central Asia and the establishment of the Gendarme Police Department of the Trans-Caspian Military Railway to protect and maintain order on it. The author examines the basic information about its staff, functions and tasks of activity in 1865-1905.
\end{abstract}

Keywords: Central Asia, Russian Turkestan, Trans-Caspian area, Trans-Caspian (Central Asian) railway, gendarme police administration, extreme protection

\section{УДК 930+ 94(510)}

КАЛЬМИНА Лилия Владимировна - доктор исторических наук, доцент; ведущий научный сотрудник отдела истории, этнологии и социологии Института монголоведения, буддологии и тибетологии СО РАН (670047, Россия, Республика Бурятия, г. Улан-Удэ, ул. Сахьяновой, 6; kalminal@gmail.com) Курас Леонид Владимирович - доктор исторических наук, профессор; главный научный сотрудник отдела истории и культуры Центральной Азии Института монголоведения, буддологии и тибетологии СО РАН (670047, Россия, Республика Бурятия, г. Улан-Удэ, ул. Сахьяновой, 6; kuraslv@ yandex.ru)

\section{ГОРЯЧИЙ РУБЕЖ ВЕКОВ: ПРИЧИНЫ БОКСЕРСКОГО ВОССТАНИЯ В КИТАЕ 1898- 1901 гг. В ГАЗЕТЕ «ВОСТОЧНОЕ ОБОЗРЕНИЕ»}

\begin{abstract}
Аннотация. В статье анализируются причины Боксерского восстания в Китае в 1898-1901 гг., прозвучавшие на страницах выходившей в Иркутске газеты «Восточное обозрение». В ее материалах, почерпнутых из российской и зарубежной прессы, нашли отражение две основные позиции по природе китайских событий: восстание как ответная реакция Китая на стремление европейских держав перестроить его жизнь по своему образцу и китайские события как результат внутренних противоречий в правящей верхушке. Умение провинциального издания ориентироваться в потоке информации дало ему возможность представить всю палитру мнений по вопросу, имевшему первостепенное значение для выстраивания будущих отношений России с ее восточным соседом.
\end{abstract}

Ключевые слова: «Восточное обозрение», Китай, Боксерское восстание, газетные материалы, европейские державы, партия реформаторов, восточная политика России

$\Gamma$ азета «Восточное обозрение», издававшаяся с 1882 по 1906 гг., была рупором областничества - общественно-политического течения, рассматривавшего Сибирь как территорию, оказавшуюся на положении экономической и поли- 